Ghada Dh Al-Sayagh BDS, MSc (Asst. Prof.)

Aisha A Qasim BDS, MSc (Asst. Prof.)

Karam H Jazrawi BDS, MSc (Lec.)

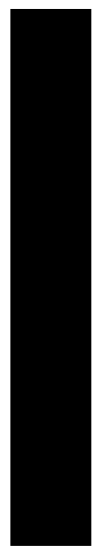

\section{Association Between Weight and Height of Children and Eruption of Permanent Teeth in Mosul City Center-Iraq}

Department of Dental Basic Sciences

College of Dentistry, University of Mosul

Dept of Pedod, orthod, and Prev Dentistry

College of Dentistry, University of Mosul

Dept of Pedod, orthod, and Prev Dentistry

College of Dentistry, University of Mosul

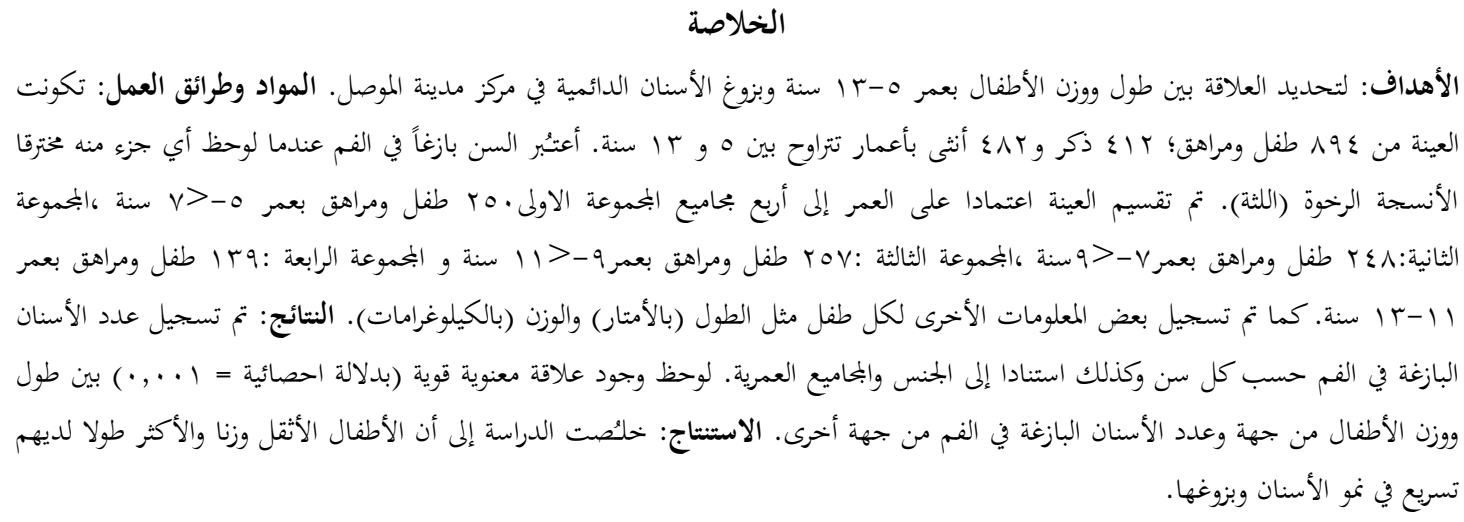

ABSTRACT

Aims: To evaluate the effect of length and weight of 5-13 years old children on eruption of permanent teeth in Mosul City. Materials and Methods: The sample consisted of 894 children and teenagers; 412 males and 482 females ranging in age from 5-13 years. A tooth was defined as erupted when any part of its crown pierced its gingiva. The sample was divided into 4 age groups: Group 1: 250 child and teenager aged 5-<7 years; group 2: 248 child and teenager aged 7-<9 years; group 3: 257 child and teenager aged 9-<11 years; and group 4: 139 child and teenager aged 11-13 years. Other information were also recorded including length of child (in meters) and weight of child (in kilograms). Results: The number of erupted teeth according to individual tooth, gender and age groups was recorded. There was a strong correlation $(p=0.001)$ between length and weight of children on one hand and number of erupted teeth on the other hand. Conclusion: Children who had higher weight and length accelerated dental development.

Key Words: Eruption of teeth, weight of child, length of child.

Al-Sayagh GD, Qasim AA, Jazrawi KH. Association Between Weight and Height of Children and Eruption of Permanent Teeth in Mosul City Center-Iraq. Al-Rafidain Dent J. 2013; 13(2): 275-281.

Received: $17 / 2 / 2012$

Sent to Referees: $18 / 2 / 2012$

\section{INTRODUCTION}

Tooth eruption is an essential process for the survival of many different species, and although the movement of teeth into function has been the subject of extensive researches there is no consensus as to the mechanism involved. ${ }^{(1)}$ The chronology of tooth eruption is very complicated. Each tooth, in each dentition, in each jaw and in each sex has its own mean eruption time. ${ }^{(2)}$

Tooth eruption is a physiological phenomenon determined as a rule by the same laws that govern the whole phylogenetic and ontogenic development of all living beings. It is a part of a physiological whole, so that the factors affecting the organism as a whole are reflected also on the growth and eruption of teeth. Human teeth do not appear simultaneously in either dentition. In general, the eruption time of permanent teeth is subjected to more variability than that observed in primary teeth. Studied on the eruption of both primary and permanent teeth have been con- 
ducted since the middle of the $20^{\text {th }}$ century. ${ }^{(3)}$

Although this process is genetically determined it is a subject to the effects of a series of important factors that cause chronological variations. ${ }^{(4)}$

The timing of eruption of the permanent dentition is of considerable importance in Child Dental Health planning of diagnostic, preventive and therapeutic measures. In the continuous process of permanent tooth eruption, the stage of clinical -or gingival- emergence is of particular interest. ${ }^{(5)}$

The timing of tooth eruption depends on a number of general factors such as: Heredity, constitution, stage of fetal development, fetal position, hormones, race, potential anomalies, climate, nutrition, various diseases. ${ }^{(6,7)}$ Local pathological conditions such as supernumerary teeth, cyst, malformation and trauma are uncommon and unlikely to have a significant effect on epidemiological data but extraction of primary antecedents is a frequent and influential local factor which does not seem to have been recognized in many studies of the ages of tooth eruption. ${ }^{(6,7)}$

Low birth weight has been inconsistently associated with dental caries. ${ }^{(8,}$ 9) Permanent teeth (first molars and central incisors, in which enamel deposition begin right after birth), ${ }^{(10)}$ are also believed to be affected by hypocalcemia observed in the first year of life of preterm/ LBW children. ${ }^{(1,12)}$

The school-age period from childhood to adolescence is a critical life stage when health and oral health behaviours develop. ${ }^{(13,14)}$

Studies have suggested that Caucasians have a delayed time of eruption when compared to other ethnic groups. ${ }^{(15,}$

16) In addition, Negroes have been shown to have an earlier eruption pattern than Caucasians. ${ }^{(17)}$

The aim of this study was to evaluate the effect of length and weight of 513years old children on the eruption of permanent teeth in Mosul City.

\section{MATERIALS AND METHODS}

This cross-sectional study was conducted on a sample collected from four kindergartens, six primary and two intermediate schools. The schools were selected randomly from the City Center of Mosul City.

The age of children was calculated from the exact date of birth and recorded in years and months.

The total sample consisted of 894 children and teenaged, 412 males and 482 females ranging age from 5-13 years. The sample was divided according to age into 4 groups as shown in Table (1).

Table (1): Distribution of sample according to age groups

\begin{tabular}{cccc}
\hline $\begin{array}{c}\text { Age Group } \\
\text { (Years) }\end{array}$ & Gender & Number & Percentage \\
\hline \multirow{5}{*}{$-<\mathbf{7}$} & Males & 103 & 41.20 \\
& Females & 147 & 58.80 \\
& Total & 250 & 27.96 \\
$\mathbf{7}-<\mathbf{9}$ & Males & 93 & 37.50 \\
& Females & 155 & 62.50 \\
& Total & 248 & 27.74 \\
$\mathbf{9}-<\mathbf{1 1}$ & Males & 126 & 49.00 \\
& Females & 131 & 51.00 \\
& Total & 257 & 28.75 \\
$\mathbf{1 1}-\mathbf{1 3}$ & Males & 90 & 64.75 \\
& Females & 49 & 35.25 \\
& Total & 139 & 15.55 \\
\hline \multirow{2}{*}{ Total Sample } & Males & 412 & 46.09 \\
& Females & 482 & 53.91 \\
& Total & 894 & 100.00 \\
\hline
\end{tabular}


Oral examination was performed in classrooms. The students were examined seated in ordinary chair under the normal daylight. The teeth were recorded as emerged or not in a special case sheet that also included other information: Age, gender, length of child (in meters) by using measuring tape, weight of child (in Kilograms) by using balance. A tooth was defined as erupted when any part of its crown pierced the gingiva, since no radiological examination was made.

The age of each child was calculated by subtracting the birth date from the examined date and then the age of child determined according to the nearest month. The children were of different socioeco- nomic level. Any child with a history of serious systemic disease was excluded.

The analysis of data was performed using SPSS version 13.0 . Analysis included frequency distribution, mean and standard deviation. Correlation coefficient was used to observe if any relation existed between length and weight of children on one hand, and number of erupted teeth on the other hand. Correlation was reported at 0.01 level.

\section{RESULTS}

Distribution of the sample with the number of the teeth according to gender was illustrated in Table (2).

Table (2): Distribution of the sample and descriptive statistics of erupted teeth according to individual teeth and gender

\begin{tabular}{|c|c|c|c|c|c|}
\hline Teeth & Gender & $\begin{array}{c}\text { No. of } \\
\text { Children }\end{array}$ & $\begin{array}{c}\text { No. of } \\
\text { Erupted Teeth }\end{array}$ & Mean & $\pm \mathrm{SD}$ \\
\hline \multirow{4}{*}{$\begin{array}{l}\text { Second Mo- } \\
\quad \text { lars }\end{array}$} & Males & 412 & 204 & 0.50 & 1.21 \\
\hline & Females & 482 & 132 & 0.27 & 0.95 \\
\hline & Total & 894 & 336 & 0.38 & 1.08 \\
\hline & Males & 412 & 1474 & 3.58 & 1.09 \\
\hline \multirow[t]{2}{*}{ First Molars } & Females & 482 & 1535 & 3.18 & 1.54 \\
\hline & Total & 894 & 3009 & 3.37 & 1.37 \\
\hline \multirow{3}{*}{$\begin{array}{l}\text { Second Pre- } \\
\text { molars }\end{array}$} & Males & 412 & 257 & 0.62 & 1.16 \\
\hline & Females & 482 & 248 & 0.51 & 1.19 \\
\hline & Total & 894 & 505 & 0.56 & 1.18 \\
\hline \multirow{4}{*}{$\begin{array}{l}\text { First Premo- } \\
\text { lars }\end{array}$} & Males & 412 & 439 & 1.07 & 1.53 \\
\hline & Females & 482 & 413 & 0.86 & 1.44 \\
\hline & Total & 894 & 852 & 0.95 & 1.49 \\
\hline & Males & 412 & 305 & 0.74 & 1.37 \\
\hline \multirow[t]{2}{*}{ Canines } & Females & 482 & 328 & 0.68 & 1.31 \\
\hline & Total & 894 & 633 & 0.71 & 1.34 \\
\hline \multirow{3}{*}{$\begin{array}{l}\text { Lateral Inci- } \\
\text { sors }\end{array}$} & Males & 412 & 975 & 2.37 & 1.83 \\
\hline & Females & 482 & 1038 & 2.15 & 1.88 \\
\hline & Total & 894 & 2013 & 2.25 & 1.86 \\
\hline \multirow{3}{*}{$\begin{array}{l}\text { Central Inci- } \\
\text { sors }\end{array}$} & Males & 412 & 1230 & 2.99 & 1.55 \\
\hline & Females & 482 & 1334 & 2.77 & 1.69 \\
\hline & Total & 894 & 2564 & 2.87 & 1.63 \\
\hline \multicolumn{2}{|c|}{ Total Males } & 412 & 4884 & 11.85 & 7.23 \\
\hline \multicolumn{2}{|c|}{ Total Females } & 482 & 5028 & 10.43 & 7.70 \\
\hline \multicolumn{2}{|c|}{ Total Sample } & 894 & 9912 & 11.09 & 7.52 \\
\hline
\end{tabular}

Also, the Table revealed number of erupted teeth according to individual teeth and gender (there were 2564, 2013, 633, $852,505,3009$, and 336 erupted teeth for centrals, laterals, cuspids, first and second bicuspids, first and second molars, respectively. The mean number of eruption for each tooth was $2.87,2.25,0.71,0.95,0.56$, 3.37 and 0.38 , respectively. Also there were 4884 and 5028 erupted teeth for total males and females, respectively. The mean number of eruption according to gender was 11.85 and 10.43 , respectively) 
Distribution of the sample with the was displayed in Table (3). number of teeth according to age groups

Table (3): Distribution of the sample and descriptive statistics of erupted teeth according to

\begin{tabular}{|c|c|c|c|c|c|}
\hline \multicolumn{6}{|c|}{ age groups } \\
\hline $\begin{array}{l}\text { Age Group } \\
\text { (Years) }\end{array}$ & Teeth & $\begin{array}{c}\text { No. of } \\
\text { Children }\end{array}$ & $\begin{array}{c}\text { No. of Erupted } \\
\text { Teeth }\end{array}$ & Mean & $\pm \mathrm{SD}$ \\
\hline \multirow{8}{*}{$5-<7$} & Second Molars & 250 & 0 & 0.00 & 0.00 \\
\hline & First Molars & 250 & 495 & 1.98 & 1.83 \\
\hline & Second Premolars & 250 & 0 & 0.00 & 0.00 \\
\hline & First Premolars & 250 & 0 & 0.00 & 0.00 \\
\hline & Canines & 250 & 0 & 0.00 & 0.00 \\
\hline & Lateral Incisors & 250 & 28 & 0.11 & 0.52 \\
\hline & Central Incisors & 250 & 188 & 0.75 & 1.14 \\
\hline & Total Teeth & 250 & 711 & 2.84 & 2.85 \\
\hline \multirow{8}{*}{$7-<9$} & Second Molars & 248 & 0 & 0.00 & 0.00 \\
\hline & First Molars & 248 & 955 & 3.85 & 0.64 \\
\hline & Second Premolars & 248 & 11 & 0.04 & 0.21 \\
\hline & First Premolars & 248 & 52 & 0.21 & 0.57 \\
\hline & Canines & 248 & 14 & 0.06 & 0.31 \\
\hline & Lateral Incisors & 248 & 515 & 2.08 & 1.65 \\
\hline & Central Incisors & 248 & 831 & 3.35 & 1.12 \\
\hline & Total Teeth & 248 & 2378 & 9.59 & 3.10 \\
\hline \multirow{8}{*}{$9-<11$} & Second Molars & 257 & 70 & 0.27 & 0.86 \\
\hline & First Molars & 257 & 1018 & 3.96 & 0.30 \\
\hline & Second Premolars & 257 & 200 & 0.78 & 1.19 \\
\hline & First Premolars & 257 & 386 & 1.50 & 1.50 \\
\hline & Canines & 257 & 260 & 1.01 & 1.38 \\
\hline & Lateral Incisors & 257 & 976 & 3.80 & 0.68 \\
\hline & Central Incisors & 257 & 1025 & 3.99 & 0.14 \\
\hline & Total Teeth & 257 & 3935 & 15.31 & 4.35 \\
\hline \multirow{8}{*}{$11-13$} & Second Molars & 139 & 266 & 1.91 & 1.82 \\
\hline & First Molars & 139 & 541 & 3.89 & 0.56 \\
\hline & Second Premolars & 139 & 294 & 2.12 & 1.64 \\
\hline & First Premolars & 139 & 414 & 2.98 & 1.47 \\
\hline & Canines & 139 & 359 & 2.58 & 1.57 \\
\hline & Lateral Incisors & 139 & 494 & 3.55 & 1.23 \\
\hline & Central Incisors & 139 & 520 & 3.74 & 0.93 \\
\hline & Total Teeth & 139 & 2888 & 20.78 & 6.64 \\
\hline
\end{tabular}

Table (4) revealed the correlation between length and weight of children on one hand, and number of erupted teeth on the other hand. There was a strong correlation $(p=0.001)$ between length of children and number of the erupted teeth for males, females and the total sample $(r=0.752$, 0.843 and 0.804 , respectively). Also there was a strong correlation $(p=0.001)$ between weight of children and number of 
the erupted teeth for males, females and 0.722 , respectively)

the total sample $(\mathrm{r}=0.658,0.838$, and

Table (4): Correlation coefficient between length and weight, and number of erupted teeth according to gender

\begin{tabular}{cccc}
\hline Sample & Pearson Correlation & Length & Weight \\
\hline \multirow{3}{*}{ Males } & r-value & 0.752 & 0.658 \\
& $\boldsymbol{p}$-value & $0.001^{*}$ & $0.001^{*}$ \\
& No. & 412 & 412 \\
Females & r-value & 0.843 & 0.838 \\
& $\boldsymbol{p}$-value & $0.001^{*}$ & $0.001^{*}$ \\
& No. & 482 & 482 \\
\hline \multirow{3}{*}{ Total Sample } & r-value & 0.804 & 0.722 \\
& $\boldsymbol{p}$-value & $0.001^{*}$ & $0.001^{*}$ \\
& No. & 894 & 894 \\
\hline
\end{tabular}

* Correlation is significant at the 0.01 level.

Similarly, the correlation was strong between length and weight of children on one hand, and number of erupted teeth on the other hand for each age group as illustrated in Table (5) (For the correlation between length and erupted teeth, $r=0.403$,
$0.481,0.464$, and 0.262 for each age group, respectively. For the correlation between the weight and the number of erupted teeth, $\mathrm{r}=0.398,0.408,0.387$, and 0.350 for each age group, respectively).

Table (5): Correlation coefficient between length and weight, and number of erupted teeth according to age groups

\begin{tabular}{cccc}
\hline $\begin{array}{l}\text { Age Group } \\
\text { (Years) }\end{array}$ & Pearson Correlation & Length & Weight \\
\hline & r-value & 0.403 & 0.398 \\
$\mathbf{5}-<\mathbf{7}$ & $\boldsymbol{p}$-value & $0.001^{*}$ & $0.001^{*}$ \\
& No. & 250 & 250 \\
& r-value & 0.481 & 0.408 \\
$\mathbf{7}-<\mathbf{9}$ & $\boldsymbol{p}$-value & $0.001^{*}$ & $0.001^{*}$ \\
& No. & 248 & 248 \\
& r-value & 0.464 & 0.387 \\
$\mathbf{9}-<\mathbf{1 1}$ & $\boldsymbol{p}$-value & $0.001^{*}$ & $0.001^{*}$ \\
& No. & 257 & 257 \\
\hline \multirow{2}{*}{$\mathbf{1 1}-\mathbf{1 3}$} & r-value & 0.262 & 0.350 \\
& $\boldsymbol{p}$-value & $0.002^{*}$ & $0.001^{*}$ \\
& No. & 139 & 139 \\
\hline
\end{tabular}

* Correlation is significant at the 0.01 level.

\section{DISCUSSION}

Variation in the normal eruption of teeth is common finding but significant deviation from established norms should alert the clinician to take some diagnostic procedures in order to evaluate patient health and development.

In the present study the number of erupted teeth according to individual teeth and gender was similar to that of other study. ${ }^{(17)}$ Similarly, the mean of eruption of each erupted tooth in the present study was similar to that presented by other study. ${ }^{(18)}$ The mean of eruption of teeth according to gender was similar to that of other study. ${ }^{(19)}$

Distribution of erupted teeth according to age groups in the present study was in agreement with that of other study. ${ }^{(20)}$ On the other hand, mean of erupted teeth for each age group was in accordance with that described by Hilgers et al. ${ }^{(21)}$

There was a strong correlation between length and weight of children, and 
number of erupted teeth for males, females and the total sample. These results were comparable to other studies. ${ }^{(3,19)}$

Similarly, there was a strong positive correlation between length and weight of children and number of the erupted teeth for each age group. Results of the present study strongly supported with those described elsewhere in the rate of the dental development compared to normal children. ${ }^{(19)}$

Children with high length and weight had higher eruption rate. This finding was consistent with the results of the study in the USA in which over-weight children had a large number of the erupted teeth. ${ }^{(21)}$ A study of a Brazilian children also detected this association. Moreover it was concluded that both weight and height influence tooth eruption. ${ }^{(22)}$

Stage of dental development height and weight are used to measure the state of over-growth. ${ }^{(23)}$ Obesity is considered to be the most common cause to accelerate growth. $^{(24,25)}$

A positive association between body height and weight, and teeth emergence has been established in the earlier studies. ${ }^{(25,26)}$

In obese children, suggest that sex hormone may play a key role in the acceleration of bone maturation. ${ }^{(28)}$ Hormonal change in the obese patient may affect mineral metabolism. ${ }^{(29)}$ It likely that the metabolic changes caused by obesity that have an impact on bone growth also affect tooth eruption. ${ }^{(28)}$

Further study showed different results, in which body condition was found to affect eruption in only one of five population; hence no consistent link between body condition and eruption was found. ${ }^{(30)}$

\section{CONCLUSION}

Children who had higher weight and length had accelerate dental development, even after adjusting for age and gender. Accelerate dental development variable to consider in pediatric dental and orthodontic treatment planning were timing is crucial.

\section{REFERENCES}

1. Rajic Z, Rajic-Mestrovic S, Verzak Z. chronology, dynamics and period of per- manent tooth eruption in Zagreb children. Coll Antropol. 2000; 24(1): 137-143.

2. Per R, Angeliki K. Inherited retarded eruption in the permanent dentition. J Clin Pediatr Dent. 1997; 21(3): 205-211.

3. Wan Salina WS, Nizam A, Naing L. Low birth weight and dental caries: Is there any association? J Kesihatan Masyarakat Isu Khas. 2004: 86-89.

4. Leroy R, Cecere S, Lesaffre E, Declerck D. Variability in permanent tooth emergence sequences in Flemish children. Eur J Oral Sci. 2008; 116: 11-17.

5. Hilgers KK, Kinane DE. Association between childhood obesity and dental development. Pediatr Dent. 2006; 28: 23-28.

6. Sadeghrianrizi A, Forsberg CM, Marcus C, Dahllof G. Obesity appeared associated with more pronounced prognathisms and greater facial dimensions. Craniofac Develop Obese Adolesc. 2006: 70-80.

7. Kochhar R, Richardson A. The chronology and sequence of eruption of human permanent teeth in Northern Ireland. Int $J$ Pediatr Dent. 1998; 8: 243-252.

8. Navia JM, Bian JY. Caries experience in deciduous dentition of rural Chinese children 3-5 years old in relation to the presence or absence of enamel hypoplasia. Caries Res. 1996; 30: 8-15.

9. Shulman JD. Is there an association between low birth weight and dental caries in the primary dentition? Caries Res. 2005; 39: 161-167.

10.Cate T. Oral Histology: Development, Structure and Function. $5^{\text {th }}$ ed. MosbyYearbook. Saint Louis. 1998.

11. Vik T, Markestad T, Ahlsten G, Jacobsen G, Bakketeig L. Morbidity during the first year of life in small for gestational age infants. Archs Dis Child. Fetal and Neonatal Edition. 1996; 75: 33-37.

12.Backstrom MC, Aine L, Maki R, Kuusela AL, Sievanen H, Koivisto AM, Ikonen RS, Maki M. Maturation of primary and permanent teeth in preterm infants. Archs Dis Child. Fetal and Neonatal Edition. 2000; 83: 104-108.

13.Peterson PE. The World Health Report 2003: Continuous improvement of oral health in the $21^{\text {st }}$ century - the approach of the WHO Global Oral Health Programmes. Community Dent Oral Epidemiol. 2003; 31 (suppl 1): 3-23. 
14.Kwan S, Petersen PE. Oral Health Promotion on Essential Element of a HealthPromoting School. Geneva. WHO. 2009.

15.Pahkala R, Pahkala A, Laine T. Eruption pattern of permanent teeth in a rural community in North Eastern Finland. Acta Odontol Scand. 1991; 49: 341-349.

16.Koch G, Poulsen S. Pediatric Dentistry A Clinical Approach. Munksgaard. Copenhagen. 2001.

17.Ekstrand KR, Christiansen J, Christiansen ME. Time and duration of eruption of first and second permanent molars: A longitudinal investigation. Community Dent Oral Epidemiol. 2003; 31: 44-50.

18. Moslemi M. An epidemiological survey of the time and sequence of eruption of permanent teeth in 4-15 year-olds in Tehran, Iran. Int J Pediatr Dent. 2004; 14: 432438.

19.Booshehri MZ, Ardakani FE, Aghili HA, Sharifi A. Assessment of the relationship between body mass index (BMI) and dental age. Health. 2011; 3(5): 253-257.

20.Mugonzibwa EA, Kuijpers-Jgtman AM, Laine-Alava MT, Van Hof MA. Emergence of permanent teeth in Tanzanian children. Community Dent Oral Epidemiol. 2002; 30: 455-462.

21.Hilgers DE, Akridge M, Scheetz JP, Kinane DE. Childhood obesity and dental development. Pediatr Dent. 2006; 28: 1622.

22.Haddad AE, Correa MS. The relationship between the number of erupted primary teeth and the child's height and weight: A cross-sectional study. J Clin Pediatr Dent. 2005; 29: 357-362.

23.Demirjan A, Buschang R, Tanguay R,
Patterson K. Inter-relationship among measure of somatic skeletal dental and sexual maturity. Am J Orthod. 1985; 88: 433.

24.Pietrobelli A, Flodmark CE, Lissau I, Moreno LA, Widhalm K. From birth to adolescence, Vienna 2005. European Childhood Obesity Group International Workshop. Int J Obes. 2005; 29(suppl 2): s1-s6.

25.Almonaitiene R, Balciuniene I, Tutkuviene J. Factors influencing permanent teeth eruption. Part One: General factors. Stomatogija, Baltic Dent Maxillofac J. 2010; 12: 67-72.

26.Billewicz WZ, McGregor IA. Eruption of permanent teeth in West African (Gambian) children in relation to age, sex. Ann Hum Biol. 1975; 2: 117-128.

27.Reinehr T, de Sousa G, Wabitsch M. Relationship of / DF - / and androgens to skeletal maturation in obese children and adolescents. $J$ Pediatr Endocraniol Metabol. 2006; 19: 1133-1140.

28.Perez LS, Irigoyen M, Zepeda M. Dental caries, tooth eruption timing and obesity: A longitudinal study in a group of Mexican school children. Acta Odontol Scand. 2010; 68: 57-64.

29. Yasunaga T, Furukawa S, Katsumata N, Horikawa R, Tanaka T, Tanae A, et al. Nutrition related hormonal changes in obese children. Endocraniol J. 1998; 45: 221-227.

30.Leo LE, Meisingset EL, Mysterud A, Langvatn R, Stenseth NC. Phenotypic and environmental correlates of tooth eruption in red deer. Cerrus Elaphus. 2004; 262: 83-89. 